\title{
Deep-sea octocorals and antipatharians show no evidence of seamount-scale endemism in the NW Atlantic
}

\author{
Jana N. Thoma*, Eric Pante*, Mercer R. Brugler, Scott C. France ${ }^{* *}$ \\ University of Louisiana at Lafayette, Department of Biology, PO Box 42451, Lafayette, Louisiana 70504, USA
}

\begin{abstract}
Seamounts are undersea mountains commonly characterized by accelerated currents, exposed hard-substrates, and relatively high biomass and biodiversity. Hydrographic features associated with seamounts have led authors to hypothesize that benthic invertebrate populations from geographically separated seamounts (and the continental slope) may experience varying degrees of genetic isolation, resulting in high levels of endemism. While this hypothesis has been tested for multiple taxonomic groups in the Pacific, it has rarely been addressed in the Atlantic. We tested the null hypothesis that the geographic ranges of corals from NW Atlantic seamounts are restricted to individual seamounts. We examined 188 octocoral and 50 antipatharian colonies (representing 6 and 2 genera, respectively) from 14 seamounts, spanning $1700 \mathrm{~km}$, and the adjacent continental margin and estimated their genetic variation using mitochondrial loci ( $m s h 1$ for all octocorals, as well as an intergenic region for isidids, and 3 multi-gene spanning segments for antipatharians). Well-sampled haplotypes were not geographically isolated on individual seamounts, thus refuting the hypothesis of local endemism of coral fauna on the New England and Corner Seamounts. The narrow geographic distribution of rare haplotypes is most likely due to undersampling rather than endemism. Our results do not preclude that cryptic variation and endemism not revealed by mitochondrial DNA may become evident should more variable markers be developed.
\end{abstract}

KEY WORDS: Endemism - Biogeography · Marine connectivity · Dispersal · Chrysogorgiidae · Paramuricea $\cdot$ Black coral $\cdot$ Anthozoa

\section{INTRODUCTION}

Seamounts, undersea mountains that rise from the sea floor, constitute a distinct deep-sea environment characterized by accelerated currents, exposed hardsubstrates, and relatively high biomass and biodiversity (reviewed by Rogers 1994). It has been hypothesized that the topographic and hydrographic conditions associated with seamounts contribute to faunal isolation and the accumulation of highly endemic taxa (coined the 'seamount endemicity hypothesis' by McClain et al. 2009; see also Hubbs 1959, Wilson \& Kaufmann 1987, Richer de Forges et al. 2000). While some studies have reported remarkably high levels of seamount endemism (e.g. Parin et al. 1997, Richer de

*Jana N. Thoma and Eric Pante have contributed equally to this project

${ }^{* *}$ Corresponding author. Email: france@louisiana.edu
Forges et al. 2000), recent reviews on seamount biodiversity warn that generalizations are difficult to make, since levels of endemism are wide-ranging and depend on the taxa and biogeographic regions under study (McClain 2007, Stocks \& Hart 2007). Indeed, gaps in our understanding of faunal endemism on seamounts are mostly tied to undersampling across the diversity of seamount environments (e.g. depth range, steepness, geological origin, habitat composition and water column productivity) and geographical locations (e.g. latitude and isolation from continental margins). Of the 100000 seamounts thought to exist worldwide (Kitchingman et al. 2007), only a few hundred have been biologically sampled (Stocks 2009), and most of these were only visited once (K. Stocks pers. comm.). 
Therefore, gathering data allowing us to identify species pools, at local, regional and global scales, to determine the geographic distribution of seamount taxa and to establish faunal affinities between biogeographic regions is still central to seamount research.

McClain (2007) and Stocks \& Hart (2007) suggested that a more synthetic understanding of the uniqueness of seamount fauna will come from (1) reducing sampling bias by visiting seamounts from a wider geographical range, (2) estimating endemism at different, well-defined spatial scales, and (3) incorporating molecular methods in the evaluation of faunal isolation. To date, research efforts have been highly skewed toward the Indo-Pacific region, and most of the data on Atlantic seamounts were gathered on northeastern chains (see Wilson \& Kaufmann 1987, Mironov \& Gebruk 2006, Stocks \& Hart 2007 for a review of worldwide seamount endemism to mid-2005). The NW Atlantic, on the other hand, has been given very little attention. Also, most studies compare faunal assemblages from seamounts and slopes, or from seamounts belonging to different seamount chains. On the other hand, few studies focus on finer spatial scales, such as the geographical distribution of individual taxa within and among seamounts (Wilson \& Kaufmann 1987, McClain 2007, Stocks \& Hart 2007). Finally, most estimates of endemism on seamounts rely on the identification of specimens from morphological characters, which can be biased by phenotypic plasticity as well as convergent evolution and cryptic variation (e.g. Avise 2004).

The New England Seamounts (NES) and Corner Seamounts (CS) offer a suitable framework for the evaluation of the seamount endemicity hypothesis, even though their fauna have only recently begun to be documented (Moore et al. 2003, 2004 and references therein). These seamount chains were formed by a mantle-plume hotspot at the Mid-Atlantic Ridge and subsequent spreading of the seafloor (Sleep 1990), and extend for approximately $1700 \mathrm{~km}$ between the North American continental margin and Mid-Atlantic Ridge (Fig. 1). The oldest seamounts (e.g. Bear Seamount) are found in association with the continental margin (Duncan 1984), which also contains numerous canyons where hard substrates are exposed. Hydrography around the NES is affected by the flow of the Gulf Stream between Kelvin and Rehoboth Seamounts (e.g. Richardson 1981), and predicted current patterns show that the NES and adjacent continental margin may be hydrographically connected to each other but isolated from the eastern CS chain (Qiu 1994), although Bower et al. (2009) showed at least some deep subsurface floats flowed from the CS westward to the NES.

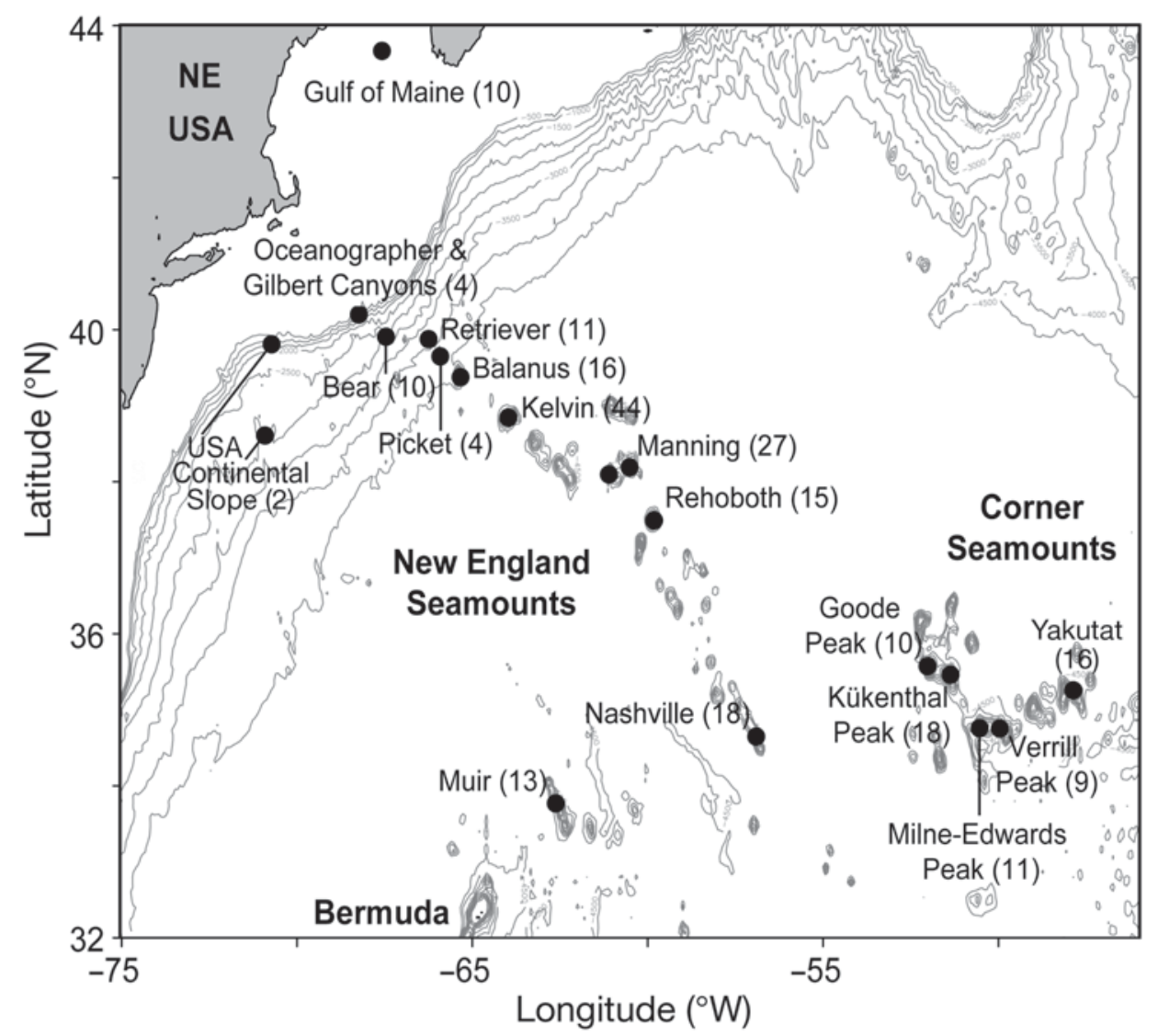

Fig. 1. Study region in the NW Atlantic. The total number of colonies collected and analyzed is given in parentheses for each collection site. Contour lines correspond to $500 \mathrm{~m}$ isobaths and extend to $4500 \mathrm{~m}$ 
We characterized the geographic distribution of genetic types, or haplotypes, of representative octocorals and antipatharians within and across the NES and CS chains. Octocorals and black corals are common and conspicuous sessile fauna on seamounts (e.g. Rogers et al. 2007), which make them appropriate model systems for the evaluation of endemism on the NES and CS chains. Determining actual levels of endemism is impracticable, since it would require a complete catalog of deep-sea habitats and associated fauna. However, endemism of a particular taxon can be refuted if it is sampled outside of its hypothesized distributional area. Therefore, we evaluated the null hypothesis that haplotypes would be restricted, or endemic, to individual seamount peaks rather than being more widely distributed. We used mitochondrial (mt) DNA markers to avoid the confounding effects of phenotypic variation, cryptic variation and convergent evolution of morphological characters. In addition to geographically mapping the distribution of haplotypes, we constructed a haplotype network for Paramuricea (a particularly abundant and diverse octocoral genus in our study area) using specimens from within and outside the NW Atlantic to provide additional insight into biogeographic patterns. Our results provide information on the biodiversity, geographic distribution and inferred dispersal potential of octocorals and black corals, which may prove useful for future management and conservation of the NW Atlantic deep-sea benthic fauna.

\section{MATERIALS AND METHODS}

Sampling. Most specimens were collected during the Mountains in the Sea and Deep Atlantic Stepping Stones expeditions of 2003-2005 (NOAA Ocean Explorer expedition logs, http:// oceanexplorer.noaa.gov/explorations/ explorations.html). A total of 188 colonies of Octocorallia Haeckel, 1866 (3 families: Chrysogorgiidae Verrill, 1883: Chrysogorgia Duchassaing \& Michelotti, 1864, Iridogorgia Verrill, 1883, Metallogorgia Versluys, 1902 and Radicipes Stearns, 1883; Isididae Lamouroux, 1812: Acanella Gray, 1870; and Plexauridae Gray, 1859: Paramuricea Kölliker, 1865) and 50 colonies of Antipatharia Milne Edwards \& Haime, 1857 (1 family: Schizopathidae Brook, 1889: Bathypathes Brook, 1889 and Parantipathes Brook, 1889) were collected from 13 seamount peaks of the
NES and CS chains, Muir Seamount and 5 locations on the adjacent continental margin of the eastern USA (200 to 2860 m depth) (Fig. 1, Table 1 in Supplement 1, see www.int-res.com/articles/suppl/m397p025_app. pdf). Additional samples from the North Atlantic, Gulf of Mexico and Pacific were used for wider biogeographic comparisons, including museum specimens collected from seamounts in the vicinity of the Azores that allowed for additional inter-seamount chain comparisons (Table S1).

To better distinguish incomplete sampling from true endemism, we plotted the geographic distribution of haplotypes - unique sequences of haploid mitochondria-as a function of sample size bounded by 2 theoretical expectations (Fig. 2): (1) local endemism (a haplotype is found on a single seamount peak independent of sample size) and (2) pan-distribution (the number of seamount peaks with a particular haplotype equals the number of seamount peaks sampled). We rejected the null hypothesis of seamount-scale endemism if haplotypes were found on more than one peak (see Fig. 2). Below the dotted line in Fig. 2 we cannot reject the null hypothesis that geographic restriction is due to endemism, as we cannot differenti-

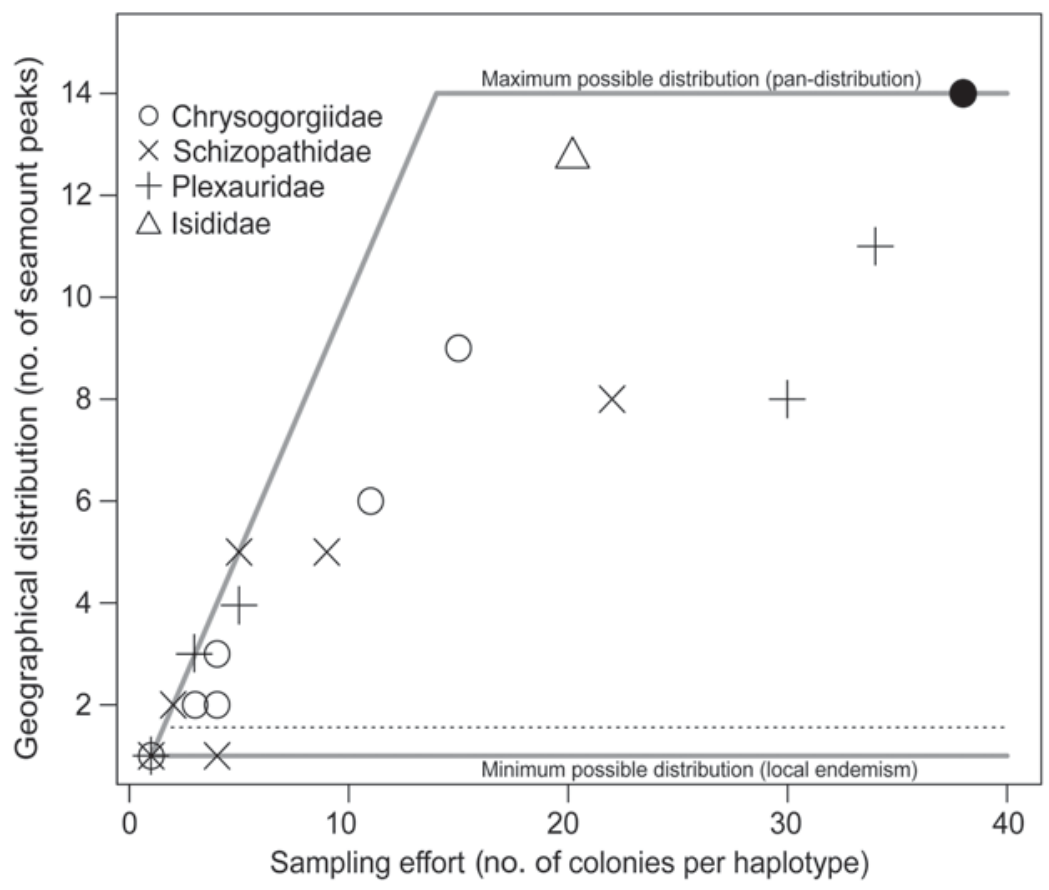

Fig. 2. Relationship between sampling effort and geographical distribution of haplotypes. Each point represents a particular haplotype; solid lines are theoretical boundaries (local endemism: haplotypes are restricted to a single seamount peak independent of sample size; pan-distribution: number of seamount peaks with a particular haplotype equals the number of colonies sampled, with an asymptote at the total seamount peaks sampled [present study, $\mathrm{n}=14]$ ). We reject the null hypothesis of endemism on individual seamounts if haplotypes are found on more than one peak (above dotted line). For example, the filled circle represents the single haplotype found for Metallogorgia melanotrichos, for which 38 colonies were sampled on 14 seamounts 
ate endemism from undersampling. However, as sampling effort across seamounts increases and haplotypes are still found on one peak (i.e. the lower right part of the plot), the likelihood for endemism increases. It is worth noting that 3 of the seamounts sampled in the present study are characterized by multiple peaks that are separated horizontally by $\sim 50$ to $75 \mathrm{~km}$ by saddles that range from 1300 to $2300 \mathrm{~m}$ deeper than the summits (e.g. Milne-Edwards and Verrill Peaks comprise Caloosahatchee Seamount, Goode and Kükenthal comprise Corner Seamount). Although fauna on the peaks are topographically isolated, it can be argued that this isolation is less significant than for fauna on separate seamounts. However, we observed no case where haplotypes were restricted to only 2 peaks on the same seamount.

DNA extraction, PCR and sequencing. Total genomic DNA was extracted from both ethanol (EtOH)-preserved and frozen material using a CTAB $(2 \%$ hexadecyltrimethylammonium bromide) protocol (with proteinase $\mathrm{K}$ in final concentration of $167 \mu^{-1}$ ) and a single chloroform-only extraction (modified from France et al. 1996).

To characterize endemism for a range of coral species on the NES and CS, we chose to sequence mtDNA as it presents few technical challenges and is cost- effective when studying species from a wide taxonomic range. Among mt markers that have been used in octocoral phylogenetics, a mismatch repair gene homolog (msh1) exhibits the highest rate of substitution and appears useful from the intrageneric to interordinal levels (16S, France et al. 1996; msh1, ND3 and ND4L, France \& Hoover 2001; $\operatorname{cox} 1$, France \& Hoover 2002, Calderón et al. 2006; ND2, ND3 and ND6, McFadden et al. 2004). Since msh1 appears to lack intraspecific variation (e.g. Lepard 2003), we associate octocoral haplotypes with individual species. This same reasoning applies to the novel mt markers used for black corals (M. R. Brugler unpubl. data). Microsatellites, which are typically more variable than mtDNA and offer resolution to the population level, were not a viable option for the present study as they generally require species-specific optimization and a larger investment of time and money, as well as greater sample sizes.

Using PCR, we amplified the $5^{\prime}$-region of $m s h 1$ for all octocorals plus, for the bamboo coral Acanella, a mt intergenic region and flanking sequence (igr4) (van der Ham et al. in press), and 5 partial genes, 1 tRNA and $3 \mathrm{mt}$ intergenic regions (IGR) for black corals (Table 1). Each PCR reaction contained $1 \mathrm{X}$ TaKaRa $E X$ Taq buffer $\left(\mathrm{Mg}^{2+}\right.$ free), $0.4 \mathrm{mM}$ dNTPs, $1.5 \mathrm{mM}$ of

Table 1. PCR primers used in the present study to amplify targeted gene regions, predicted fragment sizes (bp) using specified primer pairs and PCR cycle profiles

\begin{tabular}{|c|c|c|c|c|c|}
\hline $\begin{array}{l}\text { Amplified gene region } \\
\text { Primer }\end{array}$ & Sequence $5^{\prime} \rightarrow 3^{\prime}$ & $\begin{array}{l}\text { Fragment size } \\
\text { (primer pairs) }\end{array}$ & $\begin{array}{l}\text { Annealing } \\
\text { temp./time }\end{array}$ & $\begin{array}{l}\text { Extension } \\
\text { temp./time }\end{array}$ & Source \\
\hline \multicolumn{6}{|l|}{$\operatorname{msh} 1\left(5^{\prime}\right)$ for Octocorallia } \\
\hline (1) ND4L2475F & TAG TTT TAC TGG CCT CTA C & $\sim 990(1 \& 7)$ & $51^{\circ} \mathrm{C} / 20-30 \mathrm{~s}$ & $72^{\circ} \mathrm{C} / 50 \mathrm{~s}$ & Brugler \& France (2008) \\
\hline \multirow[t]{2}{*}{ (2) ND42625F } & TAC GTG GYA CAA TTG CTG & $\sim 845(2 \& 7)$ & $51^{\circ} \mathrm{C} / 30 \mathrm{~s}$ & $72^{\circ} \mathrm{C} / 60 \mathrm{~s}$ & Brugler \& France (2008) \\
\hline & & $\sim 495(2 \& 6)$ & $48^{\circ} \mathrm{C} / 45 \mathrm{~s}$ & $72^{\circ} \mathrm{C} / 60 \mathrm{~s}$ & \\
\hline (3) ND42599F & GCC ATT ATG GTT AAC TAT TAC & $\sim 870(3 \& 7)$ & $45^{\circ} \mathrm{C} / 45 \mathrm{~s}$ & $65^{\circ} \mathrm{C} / 60 \mathrm{~s}$ & France \& Hoover (2002) \\
\hline (4) CO3Bam5657F & GCT GCT AGT TGG TAT TGG CAT & $\sim 1000(4 \& 7)$ & $53^{\circ} \mathrm{C} / 30 \mathrm{~s}$ & $72^{\circ} \mathrm{C} / 45 \mathrm{~s}$ & Brugler \& France (2008) \\
\hline (5) MSH3010F & GGA TAA AGG TTG GAC TAT TAT AG & $\sim 460(5 \& 7)$ & $51^{\circ} \mathrm{C} / 60 \mathrm{~s}$ & $72^{\circ} \mathrm{C} / 45 \mathrm{~s}$ & \\
\hline (6) MSH3101R & GAT ATC ACA TAA GAT AAT TCC G & & & & Sánchez et al. (2003) \\
\hline (7) MUT3458R & TSG AGC AAA AGC CAC TCC & & & & Sánchez et al. (2003) \\
\hline \multicolumn{6}{|c|}{$\operatorname{cob}\left(3^{\prime}\right)$-igr4-nad6(5') for Acanella } \\
\hline (8) CytbBam1279F & AGG AGC CAA TCC AGT AGA GGA ACC & $\sim 300(7 \& 8)$ & $55^{\circ} \mathrm{C} / 30 \mathrm{~s}$ & $72^{\circ} \mathrm{C} / 45 \mathrm{~s}$ & $\begin{array}{l}\text { van der Ham et al. } \\
\text { (in press) }\end{array}$ \\
\hline (9) Nd6Bam1648R & TAY AGG TAA GAA ATG CGA GTG ATC & & & & $\begin{array}{l}\text { van der Ham et al. } \\
\text { (in press) }\end{array}$ \\
\hline \multicolumn{6}{|c|}{$\operatorname{cox} 3\left(3^{\prime}\right)$-IGR-cox1(5') for Antipatharia } \\
\hline (10) CO3gen3360F $\mathrm{F}^{\mathrm{b}}$ & CTT TGT GGC AAC TGG GTT TCA TG & $\sim 1100$ (9\&11) & $55^{\circ} \mathrm{C} / 30 \mathrm{~s}$ & $72^{\circ} \mathrm{C} / 65 \mathrm{~s}$ & \\
\hline (11) CO3anti3509F & TGG TAT TGG CAT TTT GTG GAT GT & 950 (10\&11) & $53^{\circ} \mathrm{C} / 30 \mathrm{~s}$ & $72^{\circ} \mathrm{C} / 60 \mathrm{~s}$ & \\
\hline (12) CO1gen4446R & GAT AAC ATT GCA TAA ACC ATC CCT & & & & \\
\hline \multicolumn{6}{|c|}{ nad5-5'(3')-IGR-nad1(5') for Antipatharia } \\
\hline (13) ND5-5'anti10725F & CAC ACT TGG TTG CCG GAT GCT ATG & $\sim 550(12 \& 13)$ & $55^{\circ} \mathrm{C} / 30 \mathrm{~s}$ & $72^{\circ} \mathrm{C} / 40 \mathrm{~s}$ & \\
\hline (14) ND1anti11217R & CCT AAA ACC TTN CGT TCR GCT AAA GTT & & & & \\
\hline \multicolumn{6}{|c|}{$\operatorname{trn} W$-IGR-nad2(5') for Antipatharia } \\
\hline (15) TRPantiF & GGA AGA CCG TTA GCC TTC & $\sim 700(14 \& 15)$ & $51^{\circ} \mathrm{C} / 30 \mathrm{~s}$ & $72^{\circ} \mathrm{C} / 45 \mathrm{~s}$ & \\
\hline (16) ND2anti1040R & CCA AAT AAG AAT AAG CCT GAA G & & & & \\
\hline
\end{tabular}


$\mathrm{MgCl}_{2}, 0.24 \mu \mathrm{M}$ of each primer (Operon Biotechnologies; Table 1), $2.5 \mu \mathrm{g}$ of acetylated BSA (Promega), $0.5 \mathrm{U}$ TaKaRa Ex Taq polymerase and 40 to $80 \mathrm{ng}$ of genomic DNA, and was brought to a final volume of $25 \mathrm{\mu l}$ with $\mathrm{dH}_{2} \mathrm{O}$. PCRs were run using the following cycle profile: initial denaturation at $94^{\circ} \mathrm{C}$ for $2 \mathrm{~min}$ followed by 30 to 40 cycles of denaturation at $94^{\circ} \mathrm{C}$ for 20 to $30 \mathrm{~s}$, variable annealing and extension temperatures and times based on targeted gene region (Table 1) and a final extension at $72^{\circ} \mathrm{C}$ for $6 \mathrm{~min}$. PCR products were purified by enzymatic digestion (2 U of ExoI and $0.2 \mathrm{U}$ of shrimp alkaline phosphatase [Fermentas] per $1 \mu \mathrm{l}$ of PCR product; Werle et al. 1994) or from low melting point (LMP) agarose by digestion with agarase (5 U per $100 \mu$ melted $1 \%$ LMP agarose; Sigma-Aldrich).

Purified PCR reactions were cycle-sequenced using the ABI BigDye ${ }^{\circledR}$ Terminator v1.1 Cycle Sequencing Kit (1/4 reactions) and purified using either an EtOH/EDTA precipitation or Sephadex G-50 columns (Sigma-Aldrich). Purified products were electrophoresed on an ABI PRISM ${ }^{\circledR} 3100$ or $3130 x l$ Genetic Analyzer and sequence traces were edited using Sequencher ${ }^{\mathrm{TM}}$ v4.7 (Gene Codes). DNA sequences of specimens representing each haplotype, for each seamount peak, were submitted to GenBank (Table S1).

Genetic analysis. Representative haplotypes of Paramuricea were aligned using CLUSTAL-W (Thompson et al. 1994). This alignment was submitted to DnaSP v5.00.07 (Librado \& Rozas 2009) to generate a haplotype sequence file; sites with missing data were excluded. A median-joining network was constructed using the DnaSP output file in Network 4.5.1.0 (Bandelt et al. 1999, www.fluxus-engineering.com).

\section{RESULTS}

\section{Haplotype distribution and abundance on the NES and CS}

Multiple haplotypes were found for 6 of the 8 genera analyzed; no haplotype diversity was observed among Metallogorgia and Acanella from our NW Atlantic col-

Fig. 3. Geographic distribution of haplotypes in the NW Atlantic. For each genus, sampling locations are shown by a group of 1 to 6 cells, each cell representing a haplotype (see keys). Numbers in cells are the number of colonies observed for a given haplotype. Locations are organized in a stylistic W-E and N-S orientation. GoMn: Gulf of Maine; Margin: Oceanographer and Gilbert Canyons, and 2 locations on the US Continental Slope; BEA: Bear Seamount; RET: Retriever Seamount; PIC: Picket Seamount; BAL: Balanus Seamount; KEL: Kelvin Seamount; MAN: Manning Seamount; REH: Rehoboth Seamount; NAS: Nashville Seamount; MU: Muir Seamount; GOO: Goode Peak; KUK: Kükenthal Peak; MIL: Milne-Edwards Peak; VER: Verrill Peak; YAK: Yakutat Seamount
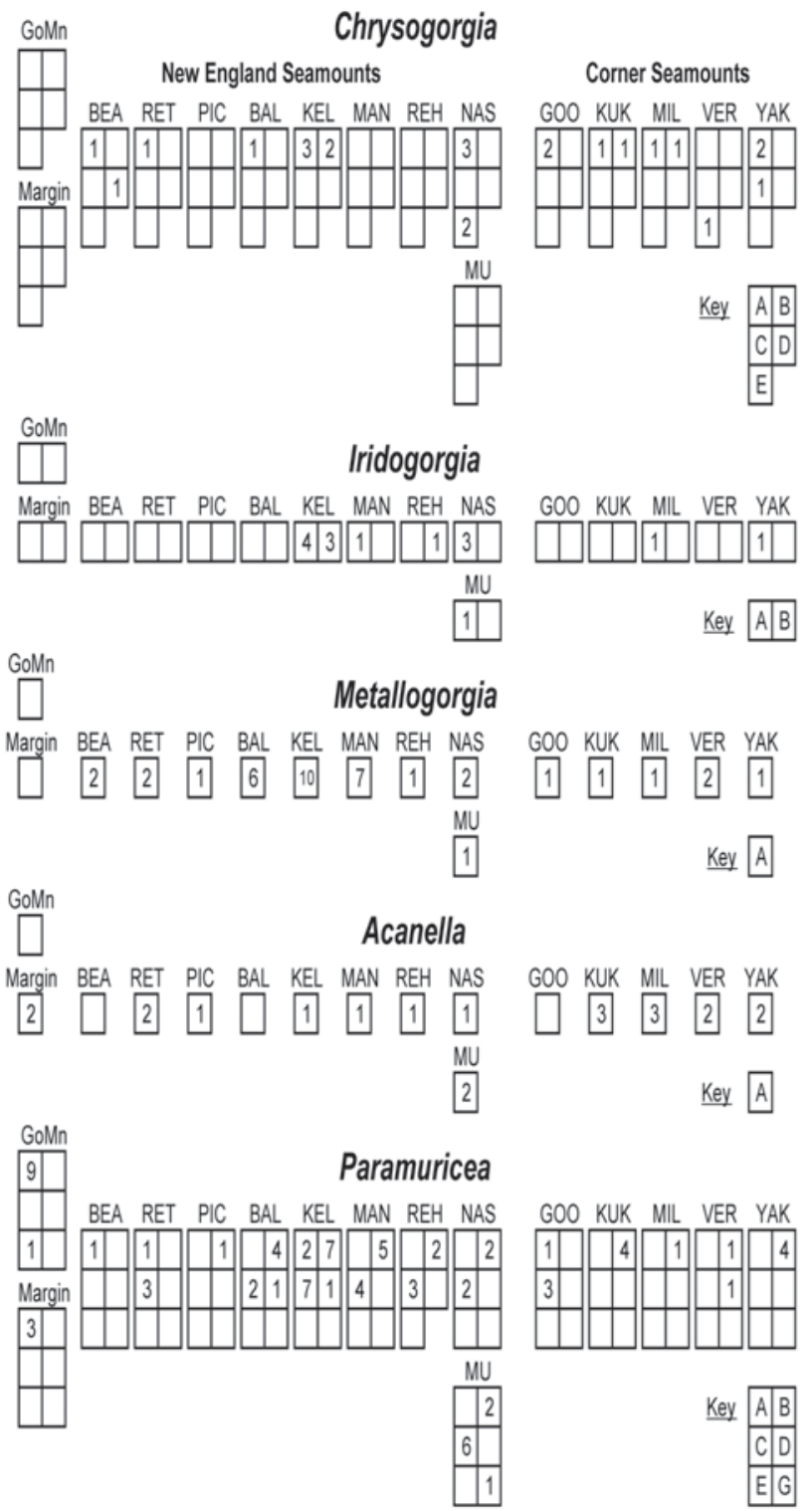

GOO KUK MIL VER YAK

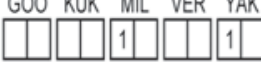

Key $A \mid B$

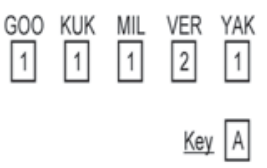

GOO KUK MIL VER YAK

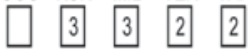

Key A
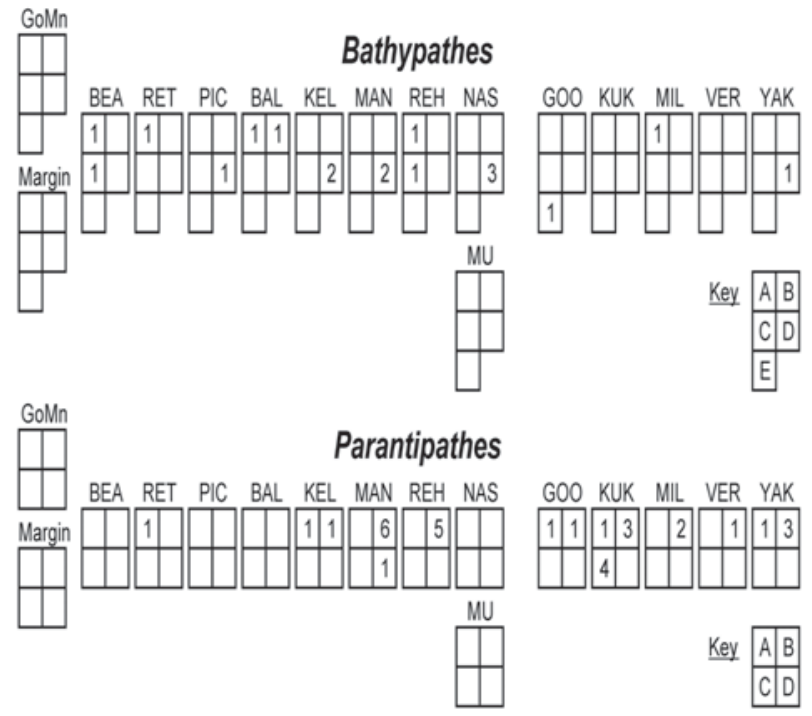

GOO KUK MIL VER YAK

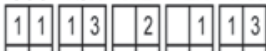

Key $A|B|$\begin{tabular}{l|l|}
\hline$A$ & $B$ \\
\hline
\end{tabular} 
Table 2. Number of colonies analyzed, $\mathrm{N}_{C}$ (from $\mathrm{N}_{\mathrm{L}}$ locations); the gene region sequenced; sequence alignment length in bp, $\mathrm{L}$ (range of sequence lengths in bp); and haplotype diversity, $\mathrm{N}_{\mathrm{H}}$ (no. colonies) from the NW Atlantic. Most variation in sequence length is due to missing data at the ends of the fragment analyzed, and not gaps in the alignment

\begin{tabular}{|c|c|c|c|c|c|}
\hline Taxon & $\mathrm{N}_{\mathrm{C}}\left(\mathrm{N}_{\mathrm{L}}\right)$ & Gene region & $\mathrm{L}$ & (Range) & $\mathrm{N}_{\mathrm{H}}$ (No. of colonies) \\
\hline \multicolumn{6}{|l|}{ Octocorallia: Chrysogorgiidae } \\
\hline Chrysogorgia & $24(10)$ & msh1 & 697 & - & A (15), B (4), C (1), D (1), E (3) \\
\hline Iridogorgia & $15(7)$ & & 700 & $(697-700)$ & $\mathrm{A}(11), \mathrm{B}(4)$ \\
\hline Metallogorgia & $38(14)$ & & 697 & - & $\mathrm{A}(38)$ \\
\hline Radicipes & $5(3)$ & & 697 & - & $A(1), B(3), C(1)$ \\
\hline \multicolumn{6}{|l|}{ Octocorallia: Isididae } \\
\hline Acanella & $21(13)$ & $\begin{array}{l}\text { msh1 } \\
\text { igr4 }\end{array}$ & $\begin{array}{l}705 \\
290\end{array}$ & $\begin{array}{c}(688-705) \\
-\end{array}$ & $\mathrm{A}(21)$ \\
\hline $\begin{array}{l}\text { Octocorallia: Plexauridae } \\
\text { Paramuricea }\end{array}$ & $85(16)$ & msh1 & 760 & $(642-760)^{\mathrm{a}}$ & $A(17), B(33), C(30), D(3), E(1), G(1)$ \\
\hline \multicolumn{6}{|l|}{ Antipatharia: Schizopathidae } \\
\hline Bathypathes & $18(11)$ & $\begin{array}{l}\text { cox3-IGR-cox1 } \\
\text { IGR-nad1 } \\
\text { IGR-nad2 }\end{array}$ & $\begin{array}{l}833 \\
405 \\
528\end{array}$ & $\begin{array}{l}(725-833) \\
(403-405) \\
(151-528)\end{array}$ & A (5), B (1), C (2), D (9), E (1) \\
\hline Parantipathes & $32(9)$ & $\begin{array}{l}\text { IGR-cox1 } \\
\text { nad5-5'-IGR-nad1 } \\
\text { trnW-IGR-nad2 }\end{array}$ & $\begin{array}{l}820 \\
474 \\
500\end{array}$ & $\begin{array}{l}(745-820) \\
(415-474) \\
(207-599)\end{array}$ & $\mathrm{A}(5), \mathrm{B}(22), \mathrm{C}(4), \mathrm{D}(1)$ \\
\hline
\end{tabular}

lections (Fig. 3, Table 2). Nine out of 27 haplotypes were sampled only once (Chrysogorgia Types C and D, Radicipes Types A and C, Paramuricea Types E and G, Bathypathes Types B and E, and Parantipathes Type D). An additional 7 haplotypes were sampled from 4 or fewer colonies, but in only one case was a haplotype restricted to a single seamount peak (Parantipathes Type C on Kükenthal, $\mathrm{n}=4$ ). These 4 Parantipathes Type $\mathrm{C}$ colonies were collected within meters of one another during a single ROV dive. Four additional Parantipathes colonies were collected from different depths on the same peak, and corresponded to haplotype A or B, both of which were distributed across multiple seamounts (Fig. 3). Of the remaining undersampled haplotypes, 2 were found on 2 different seamounts within the NES (Iridogorgia Type B and Bathypathes Type C), 2 were found on 3 different seamounts in the NES and CS (Chrysogorgia Type B and Paramuricea Type D) and 2 were found on 2 different seamounts in the NES and CS (Chrysogorgia Type E and Radicipes Type B). The geographic range of a haplotype was positively correlated with the number times it was sampled, and for those haplotypes restricted to an individual seamount, sample size was low and we could not differentiate between true endemism and undersampling (Fig. 2). Though analysis of the vertical distribution of haplotypes was constrained to the varying depth range sampled for each seamount (Fig. S1), most haplotypes found on both the NES and CS chains, with the exception of Parantipathes Type B, do not appear to be stratified by depth.

\section{Regional and global haplotype distributions}

Of the 8 genera in the present study, 4 were collected on both the geographically isolated Muir Seamount and the NES and CS chains (Fig. 3). In only a single case did we observe a haplotype restricted to Muir Seamount: Paramuricea Type G, which was represented by one specimen. Type $\mathrm{G}$ is closely related to the widespread Type $\mathrm{C}$, the most common haplotype found on Muir Seamount (Fig. 4).

We were able to sequence the $5^{\prime}$-region of $m s h 1$ for 5 museum specimens collected in 1971 and 1993 from NE Atlantic locations. Three of the specimens had haplotypes that we identified on the NES and CS chains: Iridogorgia Type A was found on the SE side of San Jorge (Portugal), Metallogorgia Type A ( $\mathrm{n}=2)$ on Plato Bank, and Chrysogorgia type B on Irving Bank. A novel Chrysogorgia haplotype was collected from Tyro Bank (Type F). Although this haplotype was not found on the NES and CS chains, we recently collected a specimen with the same haplotype on the bathyal slope of the Bahamas (E. Pante $\&$ S. C. France unpubl. data). The 3 chrysogorgiid haplotypes that were common to the NES and CS chains and NE Atlantic were also found in the Pacific (Table S1).

\section{Correspondence between genetic haplotypes and nominal species}

Six of the 27 haplotypes correspond to nominal species. Iridogorgia Type A corresponds to I. magnispiralis Watling, 2007; Type B = I. splendens Watling, 2007; 

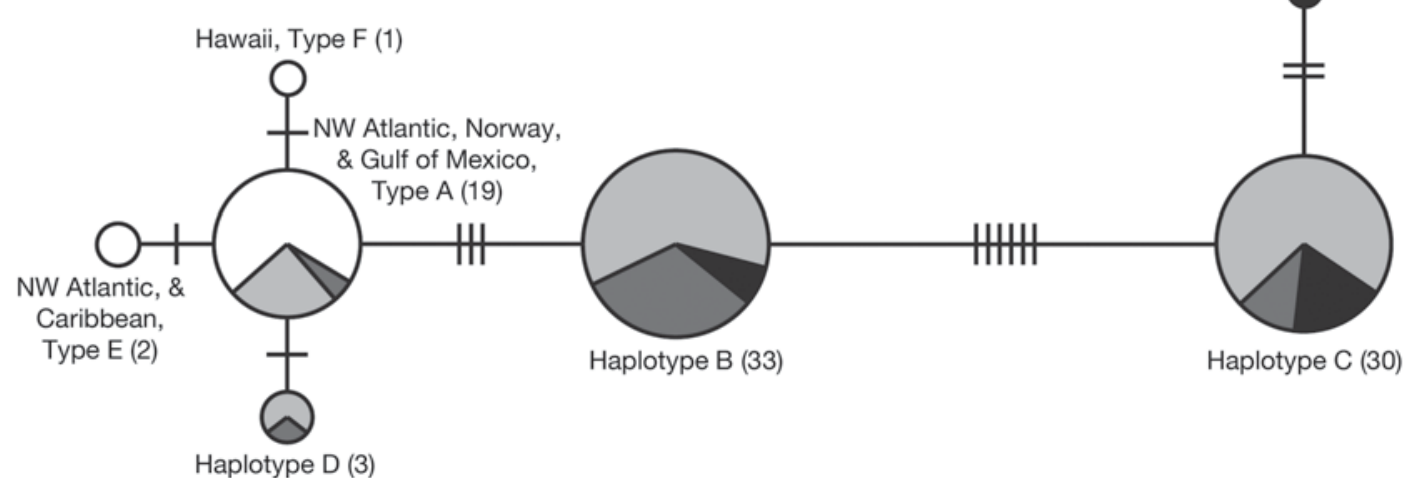

Haplotype D (3)

Fig. 4. Median-joining network depicting relatedness and geographic distribution of msh1 haplotypes of Paramuricea, based on 14 variable sites. Circle size is proportional to the number of colonies with the corresponding haplotype (sample size indicated in parentheses). Hash marks and branch lengths represent the number of mutational steps between each haplotype

Metallogorgia Type A = M. melanotrichos (Wright \& Studer, 1889); Radicipes Type A = R. gracilis (Verrill, 1884); Acanella Type A = Acanella eburnea (Pourtalès, 1868); Bathypathes Type D = B. alternata Brook, 1889. The remaining haplotypes come from colonies that are yet to be identified or are undescribed species: all types of Chrysogorgia; Radicipes Types B and $\mathrm{C}_{i}$ all types of Paramuricea; Bathypathes Types A-C and E; and Parantipathes Types A-D.

\section{Relationships among haplotypes of Paramuricea}

We observed 6 haplotypes among the 85 colonies of Paramuricea sequenced from the NW Atlantic. Although there is little overall genetic differentiation among the haplotypes, they can be divided into 3 groups (Fig. 4). Types A and E, which are the only haplotypes found on the continental margin, group together with Type D (from Balanus, Kelvin and Verrill Peak). The remaining 3 haplotypes, which were collected from seamounts only, form 2 well-separated groups (Type B versus Types C/G). Levels of divergence among haplotypes are low within the A/D/E (uncorrected $p$-distances: 0.129 to $0.268 \%)$ and $\mathrm{C} / \mathrm{G}(0.324 \%)$ groups. Types $\mathrm{B}$ and $\mathrm{C} / \mathrm{G}$ are more divergent from A/D/E (0.528 to $0.667 \%$ and 1.544 to $1.861 \%$, respectively) and from one another (1.055 to $1.238 \%$ ) (Fig. 4).

We obtained msh1 sequences from congeners collected from outside the study area (i.e. Norway, Gulf of Mexico, Caribbean and Hawaii). Specimens from Norway and the Gulf of Mexico were poorly preserved, and we could recover only partial msh1 sequences ( 208 bp); for the region of overlap their sequences were identical to group A/D/E. The sequence of the Caribbean specimen Paramuricea multispina (GenBank accession no. AY683077) is identical, except for a single ambiguity, to Type E found in a specimen from the Gulf of Maine. The ambiguous base is at a position in the alignment that is not variable in other sequences of Paramuricea or holaxonians examined (i.e. Leptogorgia chilensis, AY268460; Pseudopterogorgia americana, AY683087; Eunicea clavigera, AY683058). A complete msh1 sequence from an unidentified Paramuricea collected in Hawaii (EU293799) yielded a novel haplotype (Type F). Both haplotypes E and F differ by a single substitution from Type A.

\section{DISCUSSION}

\section{Improving geographic and taxonomic sampling}

Based on samples from 13 seamount peaks from 2 chains spanning a distance of approximately $1700 \mathrm{~km}$, the isolated Muir Seamount, and the adjacent continental margin, our study provides new data on the genetic diversity and geographic distribution of octocorals and black corals from a relatively understudied biogeographic region. To date, studies of faunal endemism on seamounts have largely been conducted in the South Pacific (Wilson \& Kaufmann 1987, Stocks \& Hart 2007). In Wilson \& Kaufmann's (1987) comprehensive review of seamount biota, only $17 \%$ of the taxa included were from the Atlantic, among which only one specimen was collected in the vicinity of our study area (San Pablo Seamount, NES; Cairns 1982 in Wilson \& Kaufmann 1987). Since 1987, several studies have characterized seamount biodiversity in the North Atlantic (Mironov \& Gebruk 2006, review to mid-2005 by Stocks \& Hart 2007), including Hall-Spencer et al. (2007), who estimated levels of endemism for corals in the NE Atlantic. Nonetheless, studies on seamount endemism in the NW Atlantic remain scarce (Sterrer 
1998, Calder 2000, see also Mironov \& Krylova 2006). This contribution, therefore, broadens the geographical breadth of the current body of research on seamount endemism.

The present study also provides data on the diversity of deep-sea corals, a relatively abundant and conspicuous, yet understudied, taxonomic group. Most studies of endemism have been conducted on fish, molluscs and crustaceans (Stocks \& Hart 2007). Our study, along with Smith et al. (2004), represents one of the rare efforts to characterize the distribution of coral species across seamounts based on genetic tools (see Baco \& Shank 2005 for a population-level study of Hawaiian deep-sea corals). While Smith et al. (2004) focused on a single octocoral subfamily (Keratoisidinae), the present study examines 3 families of octocorals as well as 2 antipatharian genera to provide information on distribution and diversity patterns from 2 distinct anthozoan lineages. We describe the distribution of 27 coral haplotypes, putatively corresponding to at least 27 species, only 6 of which could be identified based on published records. Two of these 6 identified species correspond to new species descriptions (Watling 2007) from specimens collected during the expeditions that underlie the present study. Taxonomic work on the remaining unidentified material is ongoing.

\section{Biogeography of coral haplotypes}

Seventeen of 27 coral haplotypes were not restricted to individual peaks, and 15 were not restricted to either seamount chain. For haplotypes that were restricted to individual peaks or chains, low sample size prevented us from discriminating true endemism from undersampling. In most studies that estimate endemism, the majority of taxa are not restricted to individual seamounts or seamount groups, which is evidence for successful dispersal and recruitment. In the NE Atlantic, $<3 \%$ of octocorals, black corals and scleractinians are seamount specialists (Hall-Spencer et al. 2007); therefore, we expect levels of endemism on individual seamounts to be even lower. Similar results were observed in the Pacific, where no endemism was detected for bamboo corals (Smith et al. 2004). Since we frequently observed more haplotypes with increased HOV/ROV operation time (data not shown), increasing sampling effort could expand the observed geographical range of these rare haplotypes.

Three of the 27 haplotypes were also found in the Azores and in the Pacific. These wide geographic distributions could reflect high dispersal capabilities or ancient connections between ocean basins. The absence of variation among Metallogorgia colonies, for example, contrasts with the genetic diversity observed in other chrysogorgiid genera (i.e. Chrysogorgia, Iridogorgia and Radicipes). This pattern could reflect a relatively recent origin for the genus Metallogorgia (i.e. insufficient time to speciate), or superior dispersal capability relative to confamilial species. Deep-sea corals are long-lived (e.g. Roark et al. 2006, 2009) and slow-growing (Grigg 1993), and the time needed to diversify may therefore be relatively long (e.g. diversification and longevity are negatively correlated in the rockfish Sebastes; Bonsall 2006). Thus speciation rates may be slower and the generation of endemism through in situ diversification would be expected to take longer. Finally, the slow rate of evolution of the mitochondrial markers may not reflect actual species divergence. Fukami \& Knowlton (2005) estimated the overall rate of mt genome evolution within the Montastrea annularis species complex (Scleractinia) at only 0.03 to $0.04 \%$ per million yr, and Lepard (2003) estimated the mutation rate of $m s h 1$ to range between 0.14 and $0.25 \%$ per million yr, which renders it unlikely that substitutions will be seen between lineages that have diverged less than 1 million yr ago when comparing sequences of 1000 nucleotides or less.

Our collections of Paramuricea yielded a greater number of haplotypes $(\mathrm{n}=6)$ than any other genus in our study area, and these could be divided into 3 divergent groups. One of these groups (A/D/E) was more closely related to colonies from distant locations (i.e. Norway, Gulf of Mexico, Caribbean and Hawaii) than to the other seamount haplotypes. The geographic paraphyly of NES and CS Paramuricea haplotypes, in combination with the observation of multiple, identical chrysogorgiid haplotypes found in both the Pacific and Atlantic, suggests that the 2 seamount chains are not discrete biogeographic units. A similar trend is observed for taxa of the Reykjanes Ridge (North Atlantic), which also occur in the Pacific and Antarctic (Mironov \& Gebruk 2006).

\section{Study limitations and future efforts}

Reviewers of seamount endemism (McClain 2007, Stocks \& Hart 2007) have identified geographically uneven sampling efforts and heavy reliance on morphology-based systematics as factors potentially preventing us from accurately estimating endemism at multiple spatial scales and reaching a synthetic understanding of the mechanisms involved in faunal isolation. For example, we observed that the divergent Paramuricea haplotypes come from colonies that are morphologically indistinguishable when viewed in situ. In the present study we provide molecular-based distributional information on an understudied taxonomic group from an underexplored area. Our results do not 
support seamount-scale endemism in the NW Atlantic, as well-sampled haplotypes were not geographically restricted to individual seamounts and, in some instances, haplotypes also occurred in the Pacific. Our efforts, however, are limited by gaps in the taxonomy of the concerned groups, the scarcity of samples outside of the NES and CS chains, and the potential lack of fine systematic resolution offered by currently available molecular markers.

Future efforts should focus on determining the correspondence between haplotypes and nominal species. As previously stated, preliminary efforts suggest that msh1 is appropriate for detecting variation at the species level, but ultimately, it will be necessary to formally describe all specimens collected on the NES and CS chains to establish congruence between molecular and morphological data.

At the evolutionary time-scale considered, more intensive sampling will be necessary to establish biogeographic affinities between seamount chains. Using only a few specimens from museum collections, we were able to establish that some haplotypes occur outside of the NW Atlantic. Only with sampling efforts spanning ocean basins will we be able to establish how common widely distributed taxa are. For example, samples collected during a recent expedition to the bathyal slope of the Bahamas (Bahamas Deep Corals 2009, http://oceanexplorer.noaa.gov/explorations/ 09deepseacorals/) broaden the geographical distribution of 6 haplotypes belonging to the Chrysogorgiidae (E. Pante \& S. C. France unpubl. data), 2 of which had particularly narrow ranges on the NES and CS (i.e. Iridogorgia Type B, Chrysogorgia Type C).

Developing molecular markers that are informative at the population level will provide a more complete understanding of the mechanisms involved in isolating taxa from different seamounts and seamount chains. Short sequences $(<1000 \mathrm{bp})$ of mtDNA have not been shown to be variable at the intraspecific level in most anthozoans and therefore are not suitable for population-level studies (France \& Hoover 2001， 2002, Shearer et al. 2002, McFadden et al. 2004, but see Chen et al. 2008a,b for scleractinians). Nuclear DNA, however, may be more variable than mtDNA in anthozoans (Chen et al. 2009). Low-copy nuclear markers have been used for species delineation and detection of introgression in stony corals (Hatta et al. 1999, van Oppen et al. 2000, 2001, 2004, Vollmer \& Palumbi 2002, 2007) and soft corals (Concepcion et al. 2008), and could be particularly informative for those species that might have diverged less than 1 million yr ago. Microsatellites have been used to study populationlevel questions in deep-sea corals (e.g. Baco \& Shank 2005), but they require high sample sizes. Sampling constraints in deep-sea hard-substrate communities render abundant collections of targeted taxa a difficult goal to achieve, particularly on expeditions with multiple objectives; we rarely were able to collect more than 5 colonies of a species per seamount peak.

Acknowledgements. We thank the Mountains in the Sea and Deep Atlantic Stepping Stones science parties of 2003-2005 and crews of the RV 'Ronald H. Brown' and IFE ROVs 'Argus' and 'Hercules', RV 'Atlantis' and HOV 'Alvin', and R. Etter and the crew of the RV 'Endeavor' (NSF OCE0726382). Additional samples were kindly donated by J. Moore, the NIWA Invertebrate Collection (RENEWZ I - NEW ZEEPS voyage, the first component of the project Exploration of Chemosynthetic Habitats of the New Zealand Region, funded by NOAA-OE and NIWA, with co-funding from Woods Hole Oceanographic Institution, Scripps Institution of Oceanography and the University of Hawaii) and A. Andouche, P. Bouchet and P. Maestrati (Muséum National d'Histoire Naturelle, MNHN, France). We also thank J. Adkins for the opportunity to participate in his 2003 NES cruise; L. P. Renoux and J. L. van der Ham for laboratory assistance; and L. E. Watling for his ongoing morphological work on octocorals from the NES. The manuscript was improved by comments from B. P. Thoma, A. Viricel, P. E. Rosel and 4 anonymous reviewers. Support for this research was provided by funding to S.C.F. from NSF's Ocean Sciences Division-Biological Oceanography Program (OCE-0624601), NOAA/NMFS Auke Bay Laboratory (NFFS7400-5-00022), NOAA's National Undersea Research Program (NA05OAR4301001, NA66RU0186) and NOAA-OE (NA05OAR4601061, NA03OAR4600116); to E.P. from Sigma Xi (GIAR G20061021830514629) and the American Museum of Natural History (Lerner Gray Fund); and to M.R.B. from the State of Louisiana Board of Regents Support Fund Fellowship (contract no. LEQSF(2004-09)-GF-21).

\section{LITERATURE CITED}

Avise JC (2004) Molecular markers, natural history, and evolution, 2nd edn. Sinauer Associates, Sunderland, MA, p 684

Baco AR, Shank TM (2005) Population genetic structure of the Hawaiian precious coral Corallium lauuense using microsatellites. In: Freiwald A, Roberts JM (eds) Cold-water corals and ecosystems. Springer-Verlag, Berlin, p 663-678

Bandelt HJ, Forster P, Röhl A (1999) Median-joining networks for inferring intraspecific phylogenies. Mol Biol Evol 16: $37-48$

Bonsall MB (2006) Longevity and ageing: appraising the evolutionary consequences of growing old. Philos Trans R Soc Lond B Biol Sci 361:119-135

Bower AS, Lozier MS, Gary SF, Böning CS (2009) Interior pathways of the North Atlantic meridional overturning circulation. Nature 459:243-247

Brugler MR, France SC (2008) The mitochondrial genome of a deep-sea bamboo coral (Cnidaria, Anthozoa, Octocorallia, Isididae): genome structure and putative origins of replication are not conserved among octocorals. J Mol Evol 67: $125-136$

Cairns SD (1982) Antarctic and subantarctic Scleractinia. Antarct Res Ser 34:1-74

Calder DR (2000) Assemblages of hydroids (Cnidaria) from three seamounts near Bermuda in the western North Atlantic. Deep-Sea Res I 47:1125-1139

Calderón I, Garrabou J, Aurelle D (2006) Evaluation of the utility of COI and ITS markers as tools for population 
genetic studies of temperate gorgonians. J Exp Mar Biol Ecol 336:184-197

Chen C, Chiou CY, Dai CF, Chen CA (2008a) Unique mitogenomic features in the scleractinian family Pocilloporidae (Scleractinia: Astrocoeniina). Mar Biotechnol 10:538-553

- Chen C, Dai CF, Plathong S, Chiou CY, Chen CA (2008b) The complete mitochondrial genomes of needle corals, Seriatopora spp. (Scleractinia: Pocilloporidae): an idiosyncratic atp8, duplicated trn $W$ gene, and hypervariable regions used to determine species phylogenies and recently diverged populations. Mol Phylogenet Evol 46:19-33

Chen IP, Tang CY, Chiou CY, Hsu JH and others (2009) Comparative analyses of coding and noncoding DNA regions indicate that Acropora (Anthozoa: Scleractina) possesses a similar evolutionary tempo of nuclear vs. mitochondrial genomes as in plants. Mar Biotechnol 11:141-152

Concepcion G, Crepeau M, Kahng SE, Toonen RJ (2008) An alternative to ITS: a hypervariable, single-copy nuclear intron in corals, and its use in detecting cryptic species within the octocoral genus Carijoa. Coral Reefs 27:323-336

Duncan RA (1984) Age progressive volcanism in the New England Seamounts and the opening of the Central Atlantic Ocean. J Geophys Res 89:9980-9990

France SC, Hoover LL (2001) Analysis of variation in mitochondrial DNA sequences (ND3, ND4L, MSH) among Octocorallia (=Alcyonaria) (Cnidaria: Anthozoa). Bull Biol Soc Wash 10:110-118

France SC, Hoover LL (2002) DNA sequences of the mitochondrial COI gene have low levels of divergence among deepsea octocorals (Cnidaria: Anthozoa). Hydrobiologia 471: 149-155

France SC, Rosel PE, Agenbroad JE, Mullineaux LS, Kocher TD (1996) DNA sequence variation of mitochondrial largesubunit rRNA provides support for a two subclass organization of the Anthozoa (Cnidaria). Mol Mar Biol Biotechnol $5: 15-28$

> Fukami H, Knowlton N (2005) Analysis of complete mitochondrial DNA sequences of three members of the Montastraea annularis coral species complex (Cnidaria, Anthozoa, Scleractinia). Coral Reefs 24:410-417

Grigg RW (1993) Precious coral fisheries of Hawaii and the US Pacific islands. Mar Fish Rev 55:50-60

Hall-Spencer J, Rogers A, Davies J, Foggo A (2007) Deep-sea coral distribution on seamounts, oceanic islands, and continental slopes in the Northeast Atlantic. Bull Mar Sci 81(Suppl):135-146

Hatta M, Fukami H, Wang W, Omori M and others (1999) Reproductive and genetic evidence for a reticulate evolutionary history of mass-spawning corals. Mol Biol Evol 16:1607-1613

Hubbs CL (1959) Initial discoveries of fish faunas on seamounts and offshore banks in the eastern Pacific. Pac Sci 13:311-316

Kitchingman A, Lai S, Morato T, Pauly D (2007) How many seamounts are there and where are they located? In: Pitcher T, Morato T, Hart PJB, Clark MR, Haggan N, Santos RS (eds) Seamounts: ecology, fisheries and conservation. Fisheries and Aquatic Resources Series, Blackwell, Oxford, p 26-40

Lepard A (2003) Analysis of variation in the mitochondrial encoded msh1 in the genus Leptogorgia (Cnidaria: Octocorallia) and implications for population and systematic studies. MS thesis, University of Charleston, Charleston, SC

Librado P, Rozas J (2009) DnaSP v5: a software for comprehensive analysis of DNA polymorphism data. Bioinformatics 25:1451-1452

> McClain CR (2007) Seamounts: Identity crisis or split personality? J Biogeogr 34:2001-2008
McClain CR, Lundsten L, Ream M, Barry J, DeVogelaere A (2009) Endemicity, biogeography, composition, and community structure on a Northeast Pacific seamount. PLoS One 4:e4141

McFadden CS, Tullis ID, Hutchinson MB, Winner K, Sohm JA (2004) Variation in coding (NADH dehydrogenase subunits 2, 3 and 6) and non-coding intergenic spacer regions of the mitochondrial genome in Octocorallia (Cnidaria: Anthozoa). Mar Biotechnol 6:516-526

Mironov AN, Gebruk AV (2006) Biogeography of the Reykjanes Ridge, the northern Atlantic. In: Mironov AN, Gebruck AV, Southward AJ (eds) Biogeography of the North Atlantic seamounts. KMK Scientific Press, Moscow, p 6-21

Mironov AN, Krylova EM (2006) Origin of the fauna of the Meteor Seamounts, north-eastern Atlantic. In: Mironov AN, Gebruck AV, Southward AJ (eds) Biogeography of the North Atlantic seamounts. KMK Scientific Press, Moscow, p 22-57

Moore JA, Vecchione M, Collette BB, Gibbons R and others (2003) Biodiversity of Bear Seamount, New England Seamount chain: results of exploratory trawling. J Northwest Atl Fish Sci 31:363-372

Moore JA, Vecchione M, Collette BB, Gibbons R, Hartel KE (2004) Selected fauna of Bear Seamount (New England Seamount chains), and the presence of 'natural invader' species. Arch Fish Mar Res 51:241-250

Parin NV, Mironov AN, Nesis KN (1997) Biology of the Nazca and Sala y Gómez submarine ridges, an outpost of the Indo-West Pacific fauna in the eastern Pacific Ocean: composition and distribution of the fauna, its communities and history. Adv Mar Biol 32:145-242

Qiu B (1994) Determining the mean Gulf Stream and its recirculations through combining hydrographic and altimetric data. J Geophys Res 99:951-962

> Richardson PL (1981) Gulf Stream trajectories measured with free-drifting buoys. J Phys Oceanogr 11:999-1010

Richer de Forges BR, Koslow JA, Poore GCB (2000) Diversity and endemism of the benthic seamount fauna in the southwest Pacific. Nature 405:944-947

Roark EB, Guilderson TP, Dunbar RB, Ingram BL (2006) Radiocarbon-based ages and growth rates of Hawaiian deep-sea corals. Mar Ecol Prog Ser 327:1-14

Roark EB, Guilderson TP, Dunbar RB, Fallon SJ, Mucciarone DA (2009) Extreme longevity in proteinaceous deep-sea corals. Proc Natl Acad Sci USA 106:5204-5208

Rogers AD (1994) The biology of seamounts. Adv Mar Biol 30:305-350

Rogers AD, Baco A, Griffiths H, Hart T, Hall-Spencer JM (2007) Corals on seamounts. In: Pitcher T, Morato T, Hart PJB, Clark MR, Haggan N, Santos RS (eds) Seamounts: ecology, fisheries and conservation. Fisheries and Aquatic Resources Series, Blackwell, Oxford, p 141-169

Sánchez JA, McFadden CS, France SC, Lasker HR (2003) Molecular phylogenetic analyses of shallow-water Caribbean octocorals. Mar Biol 142:975-987

Shearer TL, van Oppen MJH, Romano SL, Wörheide G (2002) Slow mitochondrial DNA sequence evolution in the Anthozoa (Cnidaria). Mol Ecol 11:2475-2487

Sleep NH (1990) Monteregian hotspot track: a long-lived mantle plume. J Geophys Res 95:21983-21990

> Smith PJ, McVeagh SM, Mingoia JT, France SC (2004) Mitochondrial DNA sequence variation in deep-sea bamboo coral (Keratoisidinae) species in the southwest and northwest Pacific Ocean. Mar Biol 144:253-261

Sterrer W (1998) How many species are there in Bermuda? Bull Mar Sci 62:809-840 
Stocks K (2009) SeamountsOnline: an online information system for seamount biology. Available at http://pacific.sdsc. edu/seamounts/

Stocks KI, Hart PJB (2007) Biogeography and biodiversity of seamounts. In: Pitcher T, Morato T, Hart PJB, Clark MR, Haggan N, Santos RS (eds) Seamounts: ecology, fisheries and conservation. Fisheries and Aquatic Resources Series, Blackwell, Oxford, p 255-281

Thompson JD, Higgins DG, Gibson TJ (1994) CLUSTAL-W: improving the sensitivity of progressive multiple sequence alignment through sequence weighting, position-specific gap penalties and weight matrix choice. Nucleic Acids Res 22:4673-4680

van der Ham JL, Brugler MR, France SC (in press) Exploring the utility of an indel-rich, mitochondrial intergenic region as a molecular barcode for bamboo corals (Octocorallia: Isididae). Mar Genomics. doi:10.1016/j.margen.2009.10.002

van Oppen MJH, Willis BL, vanVugt H, Miller DJM (2000) Examination of species boundaries in the Acropora cervicornis group (Scleractinia, Cnidaria) using nuclear DNA sequence analysis. Mol Ecol 9:1363-1373

van Oppen MJH, McDonald BJ, Willis BL, Miller DJ (2001) The evolutionary history of the coral genus Acropora (Scle-

Submitted: May 2, 2009; Accepted: September 11, 2009 ractinia, Cnidaria) based on a mitochondrial and a nuclear marker: Reticulation, incomplete lineage sorting or morphological convergence? Mol Biol Evol 18:1315-1329

van Oppen MJH, Koolmees EM, Veron JEN (2004) Patterns of evolution in the scleractinian coral genus Montipora (Acroporidae). Mar Biol 144:9-18

Vollmer SV, Palumbi SR (2002) Hybridization and the evolution of reef coral diversity. Science 296:2023-2025

Vollmer SV, Palumbi SR (2007) Restricted gene flow in the Caribbean staghorn coral Acropora cervicornis: implications for the recovery of endangered reefs. J Hered 98: $40-50$

> Watling L (2007) A review of the genus Iridogorgia (Octocorallia: Chrysogorgiidae) and its relatives, chiefly from the North Atlantic Ocean. J Mar Biol Assoc UK 87:393-402

Werle E, Schneider C, Renner M, Völker M, Fiehn W (1994) Convenient single-step, one tube purification of PCR products for direct sequencing. Nucleic Acids Res 22: 4354-4355

Wilson RR, Kaufmann RS (1987) Seamount biota and biogeography. In: Keating BH, Fryer P, Batiza R, Boehlert GW (eds) Seamounts, islands, and atolls. Geophys Monogr 43. American Geophysical Union, Washington, DC, p 355-377

Proofs received from author(s): December 7, 2009 